\title{
EVALUASI DAN STRATEGI PENINGKATAN KEBERHASILAN PELAKSANAAN PROGRAM PENGEMBANGAN USAHA MINA PEDESAAN PERIKANAN BUDIDAYA (PUMP PB): PENDEKATAN ANALISIS PROSPEKTIF
}

\section{Evaluation and Strategy on Successful Implementation of Rural Development Mina Aquaculture Business Programme (PUMP PB): Prospective Analysis Approach}

\author{
Yayan Hikmayani, Rismutia Hayu Deswati dan Zahri Nasution \\ Balai Besar Penelitian Sosial Ekonomi Kelautan dan Perikanan \\ JI. KS. Tubun Petamburan VI Jakarta 10260 \\ Telp. (021) 53650162, Fax. (021)53650159 \\ Email: yayanhikmayani@yahho.ca
}

Diterima 13 Februari 2013 - Disetujui 31 Mei 2013

\begin{abstract}
ABSTRAK
Potensi perikanan budidaya untuk mendukung pembangunan kelautan dan perikanan tergolong besar, namun belum diikuti oleh tingkat pemanfaatan yang optimal. Untuk itu, sejak tahun 2011 pemerintah telah mengimplementasikan Program Pengembangan Usaha Mina Pedesaan Perikanan Budidaya (PUMP-PB) di Indonesia. Penelitian ini bertujuan untuk mengevaluasi keberhasilan PUMP-PB dan mendapatkan strategi peningkatannya. Penelitian dilakukan pada empat lokasi contoh terpilih yaitu di Kabupaten Indramayu, Kabupaten Kolaka, Kabupaten Maros dan Kabupaten Hulu Sungai Utara yang masing-masing mewakili PUMP-PB lele, udang, rumput laut dan patin. Pengambilan sampel responden ditentukan secara sengaja. Data yang digunakan terdiri dari data primer yang dianalisis secara kualitatif dan kuantitatif dengan pendekatan analisis prospektif. Hasil penelitian menunjukkan bahwa secara umum untuk empat lokasi contoh,program PUMP-PB memiliki prospek keberhasilan yang baik di masa datang dengan enam faktor penentunya, yaitu: tingkat dan akses teknologi budidaya, ketepatan pemilihan calon lokasi, ketepatan calon penerima bantuan, luas dan status lahan, ketepatan turunnya bantuan dan dukungan kebijakan. Strategi peningkatan keberhasilan Program PUMP-PB ke depan adalah meningkatkan fasilitas pemanfaatan teknologi oleh pembuidaya seoptimal mungkin, akselerasi program pelatihan untuk pembudidaya, dan dukungan institusi terkait untuk perluasan pasar. Secara khusus, prospek keberhasilan program PUMP-PB di masa datang untuk komoditas lele dan komoditas patin tergolong baik, sedangkan untuk komoditas udang dan rumput laut tergolong cukup baik. Strategi peningkatan keberhasilan program PUMP-PB untuk komoditas lele dan patin adalah sama dengan strategi secara umum, sedangkan untuk komoditas udang dan rumput laut adalah dengan meningkatkan fasilitas akses terhadap teknologi oleh pembudidaya yang diikuti oleh peran penyediaan lembaga penyuluhan dan keterlibatan penelitian dan pengembangan kelautan dan perikanan.
\end{abstract}

Kata Kunci: program PUMP PB, Evaluasi, strategi, analisis prospektif

\begin{abstract}
The potential of aquaculture to support marine and fisheries development are considerable, but not followed by optimal utilization yet. Since 2011, Government has implemented Business Development Rural Mina Aquaculture Program (PUMP-PB) in Indonesia. This study aimed to evaluate and acquire strategies for improving the successfull of PUMP - PB. This research was carried out at four sites selected namely Indramayu District, Kolaka District, Maros District, Upper North River District, each of which represented a PUMP-PB in catfish, shrimp, seaweed and catfish (pangasius). Sampling of respondents determined intentionally. Data used is composed of primary data that were analyzed qualitatively and quantitatively with the prospective analysis approach. The results showed that the location of the program's four PUMP-PB has good success prospects in the future with six determinants, namely: level of access and technology of aquaculture, the precision of location of candidates selection,
\end{abstract}


prospective recipient accuracy, land status, the timeliness of goverment assistance and policy support. Strategy of improving the success of PUMP-PB are improving facilities utilization technology by fish farmers, accelerated training programmes for fish farmers, and related institutions to support market expansion. In particular, the prospects of success PUMP-PB in the future for pangasius and catfish commodities are good, while shrimp and seaweed are good enough. Strategy for improving the success of PUMP-PB for pangasius and catfish commodities are the same as the general strategy, as for shrimp and seaweed commodity is to improve the facilities access to technology by farmers which was followed by the support of institutions to providing counseling and involvement in research and development of marine and fisheries sector.

Keywords: PUMP-PB program, evaluation, strategy, prospective analysis

\section{PENDAHULUAN}

Budidaya Ikan sebagai salah satu usaha di bidang perikanan memiliki potensi strategis dalam mendukung salah satu tujuan pembangunan kelautan dan perikanan, yaitu meningkatkan produksi dan produktivitas usaha kelautan dan perikanan. Pencapaian tujuan tersebut ditandai dengan meningkatnya : a) Peran sektor kelautan dan perikanan terhadap pertumbuhan ekonomi nasional; b) Kapasitas sentra-sentra produksi kelautan dan perikanan yang memiliki komoditas unggulan; dan c) Pendapatan masyarakat di sektor kelautan dan perikanan (KKP 2012).

Usaha budidaya ikan harus terus didorong,karena masih besarnya potensi perikanan budidaya yang belum dimanfaatkan secara optimal. Tingkat pemanfaatan perikanan budidaya payau, baru seluas 682.857 ha atau $23,04 \%$ dari potensinya sebesar 2,96 juta ha. Tingkat pemanfaatan budidaya laut masih relatif rendah, yaitu sekitar 117.649 ha atau $0,94 \%$ dari potensi budidaya laut yang mencapai luasan 12,55 juta ha dan potensi budidaya air tawar seperti kolam 541.100 ha. Sementara, tingkat pemanfaatan perikanan budidaya di perairan umum mencapai 158.125 ha dan mina-padi 1,54 juta ha. (KKP, 2010)

Permasalahan masih rendahnya tingkat pemanfaatan lahan budidaya ikan menyebabkan masih rendahnya produktivitas budidaya. Disamping itu, masih lemahnya akses pembudidaya ikan terhadap permodalan, teknologi dan informasi pasar menyebabkan kurang optimalnya usaha budidaya. Menurut Priambodo (2013) meyatakan bahwa keterbatasan modal, rendahnya tingkat pengetahuan dan keterampilan serta teknologi merupakan masalah kronis sektor perikanan tradisional. Keterbatasan permodalan menyebabkan sulitnya pelaksanaan intensifikasi usaha budidaya oleh pembudidaya. Keterbatasan akses terhadap teknologi menyebabkan lambatnya inovasi teknologi budidaya yang dilakukan oleh pembudidaya. Disisi lain, lemahnya informasi pasar menyebabkan pembudidaya terbelenggu dengan sistem pasar yang monopolis yang sebenarnya merugikan para pembudidaya.

Permasalahan-permasalahan tersebut pada akhirnya akan menyebabkan peningkatan kapasitas para pembudidaya yang mengalami berbagai kendala. Sejak tahun 2011 Kementerian Kelautan dan Perikanan (KKP) telah mengimplementasikan Program Pengembangan Usaha Mina Pedesaan (PUMP) yang bertujuan meningkatkan produksi, produktivitas dan wirausaha. Program tersebut dialokasikan untuk seluruh kegiatan usaha di sektor kelautan dan perikanan, termasuk untuk perikanan budidaya (Program PUMP-PB) (DJPB, 2011)

Implementasi Program PUMP-PB akan dilaksanakan selama lima (5) tahun ke depan, untuk mendukung keberhasilannya selama periode tersebut diperlukan informasi hasil evaluasi dan penentuan strategi peningkatan program PUMP-PB yang tepat. Kajian evaluasi implementasi pada tahapan awal dapat memberikan kontribusi pengetahuan yang berguna untuk pelaksanaan program selanjutnya karena keberhasilan suatu program pemberdayaan merupakan resultan interaksi elemen-elemen pemberdayaan dengan strategi pemberdayaan. Hal ini di dasarkan pada ditemukannya kasus kurang berhasilnya program bantuan yang sifatnya natura karena hasilnya kurang sesuai dengan yang diharapkan (Suradisastra, 2008).

Tulisan ini disusun dengan tujuan untuk mengevaluasi Program PUMP-PB dan mendapatkan strategi peningkatan keberhasilannya dengan pendekatan analisis prospektif berdasarkan skenario-skenario yang mungkin akan terjadi di masa yang akan datang. 


\section{METODOLOGI}

Penelitian dilakukan di beberapa lokasi pelaksanaan program PUMP-PB,yaitu Kabupaten Maros (Sulawesi Selatan), Kabupaten Kolaka ( Sulawesi Tenggara), Kabupaten Indramayu (Jawa Barat) dan Hulu Sungai Utara (Kalimantan Selatan). Lokasi tersebut dipilih untuk mewakili lokasi penerima PUMP Budidaya tahun 2011 untuk komoditas ikan lele, udang, rumput laut dan patin. Waktu penelitian dilakukan selama satu bulan, yaitu Bulan Juni 2012.

Data yang dikumpulkan terdiri dari data primer dan sekunder. Data primer diperoleh dari hasil wawancara menggunakan kuesioner dengan responden penerima bantuan PUMP PB, observasi/ pengamatan lapang dan diskusi kelompok terfokus (Focus Group Discussion - FGD) dengan pakar yang mencakup para stakeholder yang terdiri dari Ditjen Budidaya, Dinas Kelautan dan Perikanan di tingkat Kabupaten. Stakeholdertersebut mempunyai pengetahuan yang komprehensif tentang program-program pemberdayaan masyarakat baik secara teknis, manajerial maupun kelembagaan. Stakeholders sebagai pakar (experts) juga dianggap menguasai dan memahami kebijakan program dan permasalahan yang dihadapi (Alston dan Bowles, 1998).

Metoda pengambilan responden dilakukan secara sengaja (purposive sampling) terhadap kelompok penerima bantuan PUMP Mandiri dalam satu wilayah desa/ per kecamatan untuk setiap kabupaten yang diamati serta yang terlibat dengan program PUMP dari perwakilan institusi. Menurut Alston dan Bowles (1998) bahwa teknik purposive sampling akan menuntun peneliti dalam memilih sampel sesuai dengan tujuan kajian/penelitian.

Data dalam penelitian ini dianalisis menggunakan pendekatan analisis prospektif dilakukan dengan tujuan untuk memprediksi kemungkinan-kemungkinan yang akan terjadi pada masa depan berdasarkan faktor-faktor yang berpengaruh (Hardjomidjojo, 2002). Faktor-faktor yang berpengaruh dalam pelaksanaan program PUMP PB sehingga dapat dijadikan sebagai acuan untuk perbaikan program tersebut ke depan. Analisis prospektif dapat memprediksi alternatif perbaikan, baik yang diinginkan maupun yang tidak diinginkan akan terjadi pada masa datang. Analisis prospektif berguna untuk: (1) Mempersiapkan tindakan strategis yang perlu dilakukan; dan (2) Melihat apakah perubahan dibutuhkan pada masa depan. Analisis prospektif tepat digunakan untuk perancangan strategi kebijakan (Godet, (2010). Menurut M.Q Patton (1987) dengan metode evaluasi tersebut dapat menganalisis apa yang dibutuhkan dan apa yang akan di lakukan.

Menurut Hardjomidjojo (2002), tahapan analisis prospektif dimulai dari tahap evaluasi kemudian diikuti dengan tahap formulasi strategi, sebagaimana dijelaskan pada uraian berikut.

\section{Tahap Evaluasi}

1. Menentukan tujuan dari sistem yang dikaji

2. Tujuan sistem yang dikaji perlu spesifik dan dimengerti oleh semua pakar yang akan diminta pendapatnya dan penyamaan pandangan tentang sistem yang dikaji. Dalam tulisan ini, tujuannya menentukan strategi keberhasilan program adalah peningkatan keberhasilan implementasi program PUMP PB

3. Identifikasi faktor-faktor yang berpengaruh dalam pencapaian tujuan tersebut, yang biasanya merupakan kebutuhan stakeholders sistem yang dikaji dan ditentukan berdasarkan penilaian para pakar.

4. Pakar diharapkan dapat mewakili stakeholders sistem yang dikaji sehingga semua kepentingan elemen sistem dapat terwakili, dan semua faktor yang teridentifikasi akan dinilai pengaruh dan ketergantunga antar faktor, dengan pedoman penilaian sebagaimana ditunjukkan padaTabel 1.

Tabel 1. Pedoman Penilaian Analisis Prospektif. Table 1. Prospective Analysis Assement Guidance.

\begin{tabular}{cl} 
Skor/Score & \multicolumn{1}{c}{ Keterangan/Description } \\
0 & Tidak ada Pengaruh/No Influence \\
1 & Berpengaruh kecil/ Less Influence \\
2 & Bepengaruh sedang/Moderate Influence \\
3 & Berpengaruh sangat kuat/ Strong Influence \\
\hline
\end{tabular}


Hasil matriks gabungan dari pendapat pakar diolah dengan perangkat lunak analisis prospektif. Hasil perhitungan digambarkan dalam diagram pengaruh dan ketergantungan antar faktor pada Gambar 1.

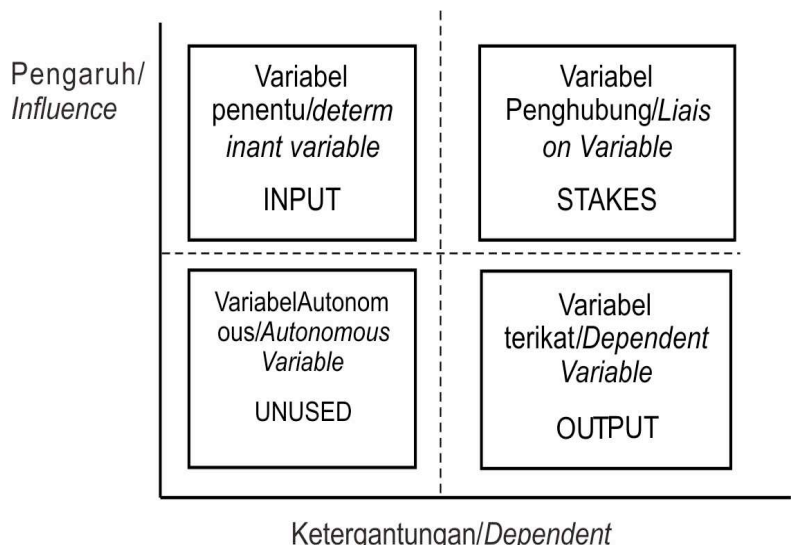

Gambar 1. Diagram Pengaruh dan Ketergantungan Sistem.

Figure 1. Influence Diagram and Dependency System.

\section{Tahap Formulasi Strategi}

1. Penyusunan keadaan yang mungkin terjadi.

Berdasarkan faktor dominan yang didapat pada tahap 3, disusun keadaan yang mungkin terjadi pada masa depan.

2. Penyusunan skenario.

Skenario harus memuat seluruh faktor, setiap faktor hanya memuat satu keadaan dan tidak memasukkan pasangan keadaan yang tidak mungkin terjadi secara bersamaan (mutual incompatibel).

3. Penentuan strategi.

Penyusunan strategi didasarkan pada pencapaian skenario yang diinginkan ataupun menghindari skenario yang berdampak negatif pada sistem.

\section{GAMBARAN UMUM PELAKSANAAN PROGRAM PUMP PERIKANAN BUDIDAYA}

\section{a. Kabupaten Indramayu}

Pada tahun 2011, Kabupaten Indramayu mendapatkan 8 paket bantuan PUMP yang diberikan untuk 8 kelompok yang memenuhi syarat dan terdiri dari sebanyak 7 kelompok pembudidaya ikan lele dan sisanya merupakan 1 kelompok pembudidaya ikan nila. Hasil pengamatan (observasi di lapang), dikeathui bahwa setelah pemberian bantuan terjadi peningkatan di beberapa bagian yaitu meningkatnya ketersediaan input produksi (benih, pakan, pupuk), bermunculannya usaha pengolahan, sudah ada pendampingan cara berbudidaya yang baik dan meningkatnya fungsi kelembagaan. Selain itu dari sisi pendapatan pembudidaya juga mengalami peningkatan. Namun di sisi lain, terdapat permasalahan dalam pelaksanaan Program PUMP PB pada tahun pertama diantaranya yaitu masih banyaknya intervensi dari berbagai pihak untuk pemilihan kelompok penerima bantuan dan masih terbatasnya kualitas dan kuantitas tenaga pendamping.

\section{b. Kabupaten Maros}

Pada tahun 2011, pelaksanaan PUMP Budidaya di Kabupaten Maros diberikan kepada 8 (delapan) kelompok petambak rumput laut yang berlokasi di Kecamatan Bontoa. Pemilihan lokasi didasarkan pada pertimbangan bahwa kecamatan tersebut merupakan sentra budidaya tambak. Sama dengan kabupaten Indramayu, pemberian bantuan melalui program PUMP-PB memberikan dampak yang positif bagi para pembudidaya rumput laut baik dari sisi produksi dan pendapatan serta peluang usaha baru. Permasalahan yang dialami di kabupaten ini juga tidak jauh dari adanya keterbatasan tenaga pendamping yang bisa menghambat penyaluran bantuan.

\section{c. Kabupaten Kolaka}

Pada tahun 2011, terdapat 4 kelompok yang mendapat bantuan dari program PUMP PB di Kabupaten Kolaka, yaitu; 2 kelompok mewakili komoditas rumput laut yang berlokasi di Kecamatan Wolo dan Latambaga dan 2 kelompok mewakili pembudidaya udang windu di Kecamatan Wolo dan Wundulako (Dinas Peternakan dan Perikanan Kabupaten Kolaka. 2012). Penyaluran program PUMP di Kabupaten Kolaka belum menunjukkan dampak positif dalam peningkatan produksi yang signifikan.Dengan adanya bantuan ini, masalah permodalan dapat teratasi sehingga penerima bantuan sudah bisa memulai budidayanya. Permasalahan yang terjadi, yaitu; telatnya pencairan bantuan PUMP yang tidak sesuai dengan musim, sehingga pembudidaya masih belum bisa memulai usahanya. 


\section{d. Kabupaten Hulu Sungai Utara}

Pada tahun 2011, kelompok penerima bantuan di Kabupaten Hulu Sungai Utara adalah kelompok pembudidaya patin di Kecamatan Kandang Haur dan Amuntai Tengah. Dampak dari bantuan PUMP ini sudah terlihat memberikan dampak positif bagi pembudidaya patin diantaranya mereka sudah mulai menggunakan cara budidaya yang sesuai dan berkembangnya usaha-usaha pengolahan patin.

\section{ANALISIS PROSPEKTIF DALAM RANGKA EVALUASI DAN PENENTUAN STRATEGI PEN INGKATAN KEBERHASILAN PELAKSANAAN PROGRM PUMP-PB}

\section{(1) Evaluasi Tingkat Keberhasilan Program PUMP-PB}

\section{Menentukan Tujuan dari Sistem yang Dikaji}

Sistem yang dikaji dalam analisis prospektif ini, berkaitan erat dengan tujuan untuk melakukan evaluasi keberhasilan Program PUMP-PB pada masa datang yang dilakukan berdasarkan 16 indikator atau faktor yang telah ditetapkan sebelumnya berdasarkan pendapatan para pakar (expert judgement), yaitu: (1) Luas pemilikan dan status lahan; (2) Ketepatan calon penerima bantuan; (3) Pengalaman pembudidaya; (4) Ketepatan komoditas; (5) Jenis usaha budidaya (kolam, keramba jaring apung, tambak); (6) Tingkat dan akses teknologi; (7) Jumlah pendamping; (8) Pengetahuan pendamping; (9) Ketepatan pemilihan lokasi; (10) Alokasi dana oleh pengguna; (11) Hubungan ketua kelompok dan anggotanya; (12) Kebutuhan modal biaya produksi; (13) Ketepatan waktu turunnya dana; (14) Ketersediaan pasar; (15) Infrastruktur; dan (16) Dukungan kebijakan pemerintah daerah. Demikian pula, evaluasi tingkat keberhasilan Program PUMP-PB tersebut merupakan rangkaian dari tahapan analisis prosepktif yang digunakan dalam penelitian ini dilakukan berdasarkan 16 indikator/faktor penentu kerbahasilan yang secara konsisiten digunakan dalam sistem yang dikaji. Hasil pengukuran tingkat keberhasilan program PUMP-PB tersebut tertera pada Tabel 2.

Berdasarkan hasil pengukuran prospek tingkat keberhasilan Program PUMP-PB (Tabel 2), diketahui bahwa untuk komoditas lele dan patin tergolong dalam klasifikasi baik atau pada masa depan memiliki indikasi program berhasil mencapai tujuan utamanya, sedangkan untuk komoditas udang dan rumput laut tergolong dalam klasifikasi cukup baik atau pada masa depan memiliki indikasi program belum berhasil mencapai tujuan utamanya.

\section{Faktor - faktor yang Mempengaruhi Keberhasilan Program PUMP-PB}

Identifikasi faktor-faktor yang berpengaruh terhadap keberhasilan pemberian bantuan PUMP-PB di lokasi survey dilakukan berdasarkan pendapat para pakar dan pelaku usaha budidaya ikan. Dalam hal ini,analisis difokuskan pada pemetaan terhadap 16 faktor penentu keberhasilan Program PUMP-PB sebagaimana telah disampaikan di atas, (Gambar 2).

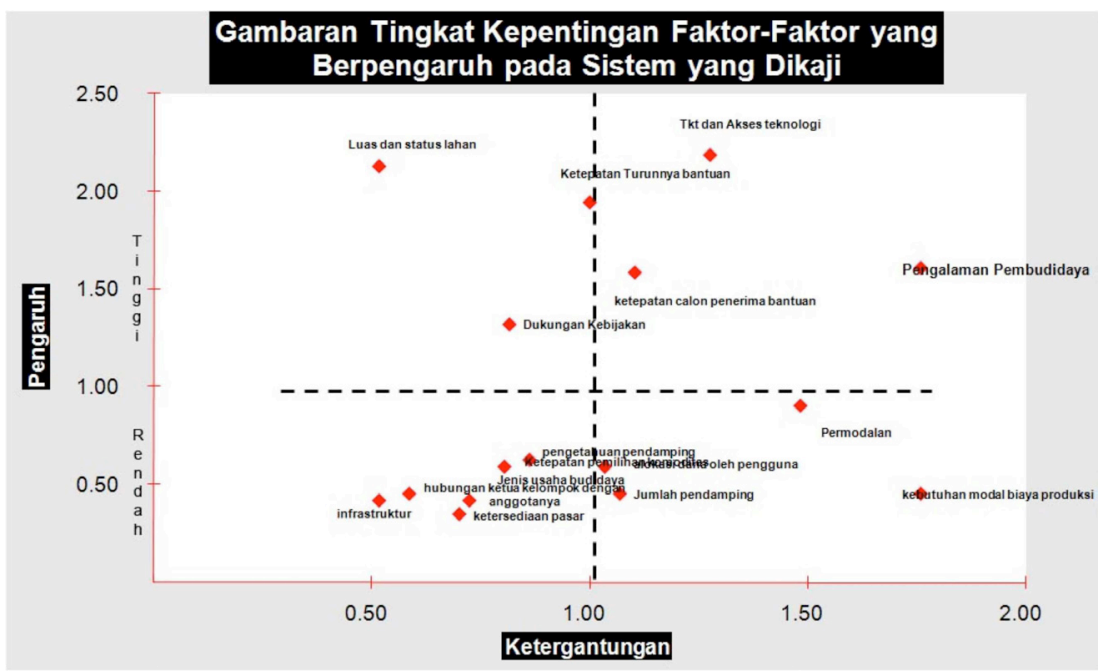

Gambar 2. Tingkat Kepentingan Faktor-faktor yang Berpengaruh Pada Sistem yang Dikaji. Figure 2. Stakeholders Needed Analysis Result. 
Tabel 2. Hasil Pengukuran Faktor Penentu dan Tingkat Keberhasilan Pelaksanaan Program PUMP-PBpada Masa Depan.

Table 2. Results Measurement and Determinants of Implementation Success Rate PUMPPB Program in the Future.

\begin{tabular}{|c|c|c|c|c|c|}
\hline \multirow[b]{2}{*}{$\begin{array}{l}\text { Indikator/Faktor } \\
\text { Indicator/Factor }\end{array}$} & \multirow{2}{*}{$\begin{array}{c}\text { Program } \\
\text { PUMP-PB } \\
\text { Keseluruhan } \\
\text { Komoditas/ } \\
\text { PUMP-PB } \\
\text { Program for AII } \\
\text { Commodities }\end{array}$} & \multicolumn{4}{|c|}{$\begin{array}{c}\text { Program PUMP-PB per Komoditas/PUMP-PB Program per } \\
\text { Commodity }\end{array}$} \\
\hline & & $\begin{array}{l}\text { Lele I } \\
\text { Catfish }\end{array}$ & Udang / Shrimp & $\begin{array}{l}\text { Rumput Laut } \\
\text { / Seaweed }\end{array}$ & $\begin{array}{c}\text { Patin / Catfish } \\
\text { (Pangasius } \\
\text { Sp) }\end{array}$ \\
\hline $\begin{array}{l}\text { 1. Luas pemilikan dan status } \\
\text { lahan / Broad ownership and } \\
\text { land status }\end{array}$ & $\begin{array}{l}\text { Meningkat / } \\
\text { Increase }\end{array}$ & $\begin{array}{l}\text { Meningkat / } \\
\text { Increase }\end{array}$ & $\begin{array}{l}\text { Kurang } \\
\text { Meningkat/Less } \\
\text { increase }\end{array}$ & $\begin{array}{l}\text { Meningkat / } \\
\text { Increase }\end{array}$ & $\begin{array}{l}\text { Meningkat / } \\
\text { Increase }\end{array}$ \\
\hline $\begin{array}{l}\text { 2. Ketepatan calon penerima } \\
\text { bantuan / The accuracy of the } \\
\text { beneficiaries prospective }\end{array}$ & $\begin{array}{l}\text { Kurang Tepat / } \\
\text { Not appropriate }\end{array}$ & $\begin{array}{l}\text { Tepat / } \\
\text { Appropriate }\end{array}$ & $\begin{array}{l}\text { Kurang Tepat / } \\
\text { Not appropriate }\end{array}$ & $\begin{array}{l}\text { Kurang } \\
\text { Tepat / Not } \\
\text { appropriate }\end{array}$ & $\begin{array}{l}\text { Tepat / } \\
\text { Appropriate }\end{array}$ \\
\hline $\begin{array}{l}\text { 3. Pengalaman pembudidaya / } \\
\text { Farmers experience }\end{array}$ & $\begin{array}{l}\text { Tinggi / } \\
\text { Advanced }\end{array}$ & $\begin{array}{l}\text { Tinggi / } \\
\text { Advanced }\end{array}$ & $\begin{array}{l}\text { Tinggi / } \\
\text { Advanced }\end{array}$ & $\begin{array}{l}\text { Sedang / } \\
\text { Average }\end{array}$ & $\begin{array}{l}\text { Tinggi / } \\
\text { Advanced }\end{array}$ \\
\hline $\begin{array}{l}\text { 4. Ketepatan pemilihan / } \\
\text { komoditas / } \\
\text { The proper selection }\end{array}$ & $\begin{array}{l}\text { Tepat / } \\
\text { Appropriate }\end{array}$ & $\begin{array}{l}\text { Tepat / } \\
\text { Appropriate }\end{array}$ & $\begin{array}{l}\text { Tepat / } \\
\text { Appropriate }\end{array}$ & $\begin{array}{l}\text { Kurang } \\
\text { Tepat / Not } \\
\text { appropriate }\end{array}$ & $\begin{array}{l}\text { Tepat / } \\
\text { Appropriate }\end{array}$ \\
\hline $\begin{array}{l}\text { 5. Jenis usaha budidaya / } \\
\text { Type of farming }\end{array}$ & $\begin{array}{l}\text { Sesuai / } \\
\text { Appropriate }\end{array}$ & $\begin{array}{l}\text { Sesuai / } \\
\text { Appropriate }\end{array}$ & $\begin{array}{l}\text { Sesuai / } \\
\text { Appropriate }\end{array}$ & $\begin{array}{l}\text { Sesuai / } \\
\text { Appropriate }\end{array}$ & $\begin{array}{l}\text { Sesuai / } \\
\text { Appropriate }\end{array}$ \\
\hline $\begin{array}{l}\text { 6. Tingkat dan akses teknologi / } \\
\text { Level and technology access }\end{array}$ & $\begin{array}{l}\text { Tinggi / } \\
\text { Advanced }\end{array}$ & $\begin{array}{l}\text { Tinggi / } \\
\text { Advanced }\end{array}$ & $\begin{array}{l}\text { Tinggi / } \\
\text { Advanced }\end{array}$ & $\begin{array}{l}\text { Sedang / } \\
\text { Average }\end{array}$ & $\begin{array}{l}\text { Tinggi / } \\
\text { Advanced }\end{array}$ \\
\hline $\begin{array}{l}\text { 7. Jumlah pendamping / } \\
\text { The number of companion }\end{array}$ & $\begin{array}{l}\text { Kurang Sesuai / } \\
\text { Not appropriate }\end{array}$ & $\begin{array}{l}\text { Sesuai / } \\
\text { Appropriate }\end{array}$ & $\begin{array}{l}\text { Kurang Sesuai / } \\
\text { Not appropriate }\end{array}$ & $\begin{array}{l}\text { Kurang } \\
\text { Sesuai / Not } \\
\text { appropriate }\end{array}$ & $\begin{array}{l}\text { Kurang } \\
\text { sesuai / Not } \\
\text { appropriate }\end{array}$ \\
\hline $\begin{array}{l}\text { 8. Pengetahuan pendamping / } \\
\text { Knowledge companion }\end{array}$ & $\begin{array}{l}\text { Memadai / } \\
\text { Adequate }\end{array}$ & $\begin{array}{l}\text { Memadai / } \\
\text { Adequate }\end{array}$ & $\begin{array}{l}\text { Memadai / } \\
\text { Adequate }\end{array}$ & $\begin{array}{l}\text { Memadai / } \\
\text { Adequate }\end{array}$ & $\begin{array}{l}\text { Memadai / } \\
\text { Adequate }\end{array}$ \\
\hline $\begin{array}{l}\text { 9. Ketepatan Pemilihan Lokasi/ } \\
\text { Appropriateness of Site } \\
\text { Selection }\end{array}$ & $\begin{array}{l}\text { Memadai / } \\
\text { Appropriate }\end{array}$ & $\begin{array}{l}\text { Memadai / } \\
\text { Appropriate }\end{array}$ & $\begin{array}{l}\text { Memadai / } \\
\text { Appropriate }\end{array}$ & $\begin{array}{l}\text { Kurang } \\
\text { Memadai/Not } \\
\text { appropriate }\end{array}$ & $\begin{array}{l}\text { Memadai / } \\
\text { Appropriate }\end{array}$ \\
\hline $\begin{array}{l}\text { 10. Alokasi dana oleh pengguna/ } \\
\text { The allocation of funds by the } \\
\text { user }\end{array}$ & $\begin{array}{l}\text { Memadai / } \\
\text { Adequate }\end{array}$ & $\begin{array}{l}\text { Memadai / } \\
\text { Adequate }\end{array}$ & $\begin{array}{l}\text { Memadai / } \\
\text { Adequate }\end{array}$ & $\begin{array}{l}\text { Memadai / } \\
\text { Adequate }\end{array}$ & $\begin{array}{l}\text { Memadai / } \\
\text { Adequate }\end{array}$ \\
\hline $\begin{array}{l}\text { 11. Hubungan ketua kelompok } \\
\text { dan anggotanya / Relations of } \\
\text { team leader and members }\end{array}$ & Baik / Good & Baik / Good & $\begin{array}{l}\text { Cukup Baik / } \\
\text { Enough }\end{array}$ & $\begin{array}{l}\text { Cukup Baik / } \\
\text { Enough }\end{array}$ & $\begin{array}{l}\text { Baik / } \\
\text { Good }\end{array}$ \\
\hline $\begin{array}{l}\text { 12. Alokasi biaya produksi / } \\
\text { Allocation of cost production }\end{array}$ & $\begin{array}{l}\text { Memadai / } \\
\text { Adequate }\end{array}$ & $\begin{array}{l}\text { Memadai / } \\
\text { Adequate }\end{array}$ & $\begin{array}{l}\text { Memadai / } \\
\text { Adequate }\end{array}$ & $\begin{array}{l}\text { Memadai / } \\
\text { Adequate }\end{array}$ & $\begin{array}{l}\text { Kurang } \\
\text { memadai / Not } \\
\text { adequate }\end{array}$ \\
\hline $\begin{array}{l}\text { 13. Ketepatan waktu turunnya } \\
\text { dana bantuan / Timeliness } \\
\text { decline in aid }\end{array}$ & $\begin{array}{l}\text { Kurang Tepat / } \\
\text { Not appropriate }\end{array}$ & $\begin{array}{l}\text { Kurang } \\
\text { Tepat / Not } \\
\text { Appropriate }\end{array}$ & $\begin{array}{l}\text { Kurang Tepat / } \\
\text { Not appropriate }\end{array}$ & $\begin{array}{l}\text { Kurang } \\
\text { tepat / Not } \\
\text { appropriate }\end{array}$ & $\begin{array}{l}\text { Kurang } \\
\text { tepat / Not } \\
\text { appropriate }\end{array}$ \\
\hline $\begin{array}{l}\text { 14. Ketersediaan pasar / } \\
\text { Availability of market }\end{array}$ & $\begin{array}{l}\text { Tersedia / } \\
\text { Available }\end{array}$ & $\begin{array}{l}\text { Tersedia / } \\
\text { Available }\end{array}$ & $\begin{array}{l}\text { Tersedia / } \\
\text { Available }\end{array}$ & $\begin{array}{l}\text { Cukup } \\
\text { Tersedia / } \\
\text { Enough }\end{array}$ & $\begin{array}{l}\text { Tersedia / } \\
\text { available }\end{array}$ \\
\hline 15. Infrastruktur / Infrastructure & $\begin{array}{l}\text { Sesuai/ } \\
\text { Appropriate }\end{array}$ & $\begin{array}{l}\text { Sesuai/ } \\
\text { Appropriate }\end{array}$ & $\begin{array}{l}\text { Kurang Sesuai/ } \\
\text { Lessappropriate }\end{array}$ & $\begin{array}{l}\text { Sesuai/ } \\
\text { Appropriate }\end{array}$ & $\begin{array}{l}\text { Sesuai/ } \\
\text { Appropriate }\end{array}$ \\
\hline $\begin{array}{l}\text { 16. Dukungan kebijakan daerah / } \\
\text { Support local policy }\end{array}$ & Positif / Positive & $\begin{array}{l}\text { Positif / } \\
\text { Positive }\end{array}$ & Positif / Positive & $\begin{array}{l}\text { Positif / } \\
\text { Positive }\end{array}$ & $\begin{array}{l}\text { Positif / } \\
\text { Positive }\end{array}$ \\
\hline $\begin{array}{c}\text { Klasifikasi Prospek Keberhasilan } \\
\text { Program PUMP-PB*)/ The prospect } \\
\text { of success Classification Program } \\
\text { PUMP-PB }\end{array}$ & Baik / Good & Baik / Good & $\begin{array}{l}\text { Cukup Baik / } \\
\text { Enough }\end{array}$ & $\begin{array}{l}\text { Cukup Baik / } \\
\text { Enough }\end{array}$ & Baik / Good \\
\hline
\end{tabular}

Sumber: Data Primer Diolah, 2012/Source : Primary Data Processed, 2012

Keterangan/Remarks:

*) Baik/ Good = Program berhasil mencapai tujuan utamanya (berhasil) pada masa depan/The program succeeded in achieving its primary objective(successfully) in the future

Cukup Baik/Good Enough =Program belum mencapai tujuan utamanya (kurang berhasil) pada masa depan/The program has not achieved its primary objective (less successful) in the future

Kurang Baik/Poor =Program tidak mencapai tujuan utamanya (tidak berhasil/gagal) pada depan/The program did not achieve its primary objective (not succeed / fail) in the future 
Berdasarkan hasil analisis, pada keempat lokasi contoh (untuk keseluruhan komoditas), dapat diketahui bahwa terdapat sebanyak enam faktor yang memiliki pengaruh sangat tinggi terhadap keberhasilan Program PUMP-PB ke depan (Gambar 2). Keenam faktor tersebut terdiri tiga faktor utama penentu keberhasilan (input factors) dan tiga faktor penghubung/ pendukung keberhasilan (stakes factors). Tiga faktor utama penentu keberhasilan Program PUMP-PB adalah: (1) Tingkat dan akses teknologi budidaya; (2) Ketepatan pemilihan calon lokasi; dan (3) Ketepatan calon penerima bantuan. Menurut Hoogerworf (1983) menyatakan bahwa kebijakan pemerintah dalam pengentasan kemiskinan belum memenuhi harapan masyarakat karena masih belum efektifnya keterpaduan dalam penyaluran dana dan penentuan sasaran baik tingkat pusat, daerah dan lokal.

Kemudian tiga faktor penghubung/ pendukungnya adalah: (1) Luas dan status lahan; (2) Ketepatan turunnya bantuan; dan (3) Dukungan kebijakan. Menurut Hoogerworf (1983) menyatakan bahwa program pengentasan kemiskinan cenderung masih menjadi kewenangan pusat.

Dengan demikian keenam faktor tersebut dapat dikatakan sebagai faktor dominan yang akan mempengaruhi atau mementukan tingkat keberhasilan Program PUMP-PB ke depan.

Faktor penentu (input factors) pada kuadran I terdiri dari luas dan status lahan, ketepatan turunnya bantuan, dan dukungan kebijakan Pemda. Ketiga faktor tersebut mempunyai pengaruh yang sangat kuat dalam menentukan keberhasilan program bantuan PUMP budidaya. Selain itu, faktor-faktor tersebut juga tidak dipengaruhi oleh faktor-faktor lainnya dalam sistem. Dari hasil tersebut, diketahui bahwa keberhasilan Program PUMP PB ditentukan oleh dukungan kebijakan pemerintah daerah, status lahan dan ketepatan turunnya bantuan.

Sementara faktor stakes (penghubung/ pendukung)yang terletak pada kuadran II terdiri dari tingkat dan akses teknologi, ketepatan pemilihan lokasi dan ketepatan penentuan calon penerima bantuan. Faktor-faktor tersebut memiliki pengaruh sangat kuat dan mempunyai ketergantungan pada sistem yang dikaji, sehingga merupakan faktor kunci yang paling berpengaruh terhadap keberhasilan program PUMP PB. Menurut
Sukadi, (2002) menyatakan bahwa faktor pemilihan lingkungan untuk budidaya ikan sangat menentukan keberhasilan kegiatan budidaya, tergolong faktor independen..

Faktor yang termasuk dalam independent factors terdapat pada kuadran III, yaitu pengalaman pembudidaya, hubungan ketua kelompok dengan anggotanya, dan ketepatan pemilihan komoditas. Faktor-faktor tersebut merupakan output dalam sistem yang dikaji,yang tidak mempunyai pengaruh dan sangat tergantung dari sistem. Faktor-faktor ini merupakan output dari faktor- faktor lainnya yang berada dalam input dan stakes. Kemudian faktor- faktor yang termasuk dalam autonomous factors terdapat pada kuadran IV yaitu :jumlah pendamping, infrastruktur, alokasi biaya dan pengetahuan pendamping. Faktor-faktor tersebut memilki pengaruh dan ketergantungan yang rendah dalam sistem yang dikaji, sehingga dapat dianggap tidak diperhitungkan sebagai faktor penting (unused factors).

\section{(2) Strategi Peningkatan Keberhasilan Program PUMP-PB}

Penentuan strategi peningkatan keberhasilan Program PUMP-PB yang dilakukan berdasarkan enam faktor penentu terhadap keberhasilan program tersebut, (sebagaimana dihasilkan dari analisis sebelumnya). Dalam prosesnya, faktor-faktor penentu tersebut digunakan dalam pengembangan skenario pelaksaaan Program PUMP-PB ke depan yang dikaitkan dengan strategi yang semetinya digunakan. Pengembangan skenario tersebut dilakukan melalui brainstorming dan diskusi kelompok terfokus (focus group discussion FGD) untuk menghasilkan perkiraan kondisi dari masing-masing variabel penentu padamasa datang (Godet, 2010).

Pengembangan skenario dalam penentuan strategi tersebut,dimaksudkan untuk memprediksi kemungkinan yang dapat terjadi pada faktor tersebut di masa mendatang, apakah akan berkembang ke arah yang lebih baik dari sekarang, tetap atau akan semakin buruk dari keadaan sekarang. Hasil ini dapat memberikan kewaspadaan bagi pengambil kebijakan untuk menjalankan strategi yang dipilih. Hoogerworf (1983) menyatakan bahwa 4 faktor yang sangat menentukan efektivitasnya kebijakan yaitu: akurasi rumusan kebijakan, kelengkapan informasi oleh pelaksana kebijakan, dukungan publik dan kualitas intelektual pelaksana kebijakan 


\section{KEADAAN YANG MUNGKIN TERJADI PADA PROGRAM PUMP.PB DI MASA DATANG}

Tabel 3 memperlihatkan pilihan keadaan yang mungkin terjadi pada implementasi Program PUMP-PB di masa depan yang dilakukan berdasarkan enam faktor kunci keberhasilan program yang telah dihasilkan dalam analisis sebelumnya. Namun dari keadaan yang mungkin terjadi tersebut,perlu dibatasi terlebih dahulu keadaan yang tidak mungkin terjadi secara bersamaan (mutually incompatible) sebagaimana tertera pada Tabel 4, Tabel 5, Tabel 6, Tabel 7 dan Tabel 8.

\section{SKENARIO PELAKSANAAN PROGRAM PUMP. PB PADA MASA DATANG}

Berdasarkan keadaan yang telah disusun pada tahap sebelumnya, yaitu kondisi-kondisi keadaan Program PUMP-PB pada masa datang (Tabel 3) yang kemudian dikoreksi dengan mengeluarkan kondisi-kondisi keadaan yang tidak mungkin terjadi bersamaan baik untuk keseluruhan komoditas (Tabel 4) maupun masing masing komoditas (Tabel 5, Tabel 6, Tabel 7, dan Tabel 8), maka disusun alternatif skenario yang mungkin terjadi untuk mendapatkan opsi strategi (rekomendasi operasional) peningkatan keberhasilan pelaksanaan program PUMP-PB di masa depan. Skenario tersebut disusun berdasarkan hasil penilaian para pakar yang dihimpun melalui kegiatan diskusi kelompok terfokus/ focus group discussion (FGD) sebagaimana tertera pada Tabel 9.

\section{PENENTUAN STRATEGI PENINGKATAN PROGRAM PUMP-PB PADA MASA DEPAN}

Setelah tersusun skenario pelaksaan program PUMP-PB, tahap selanjutnya adalah untuk mendapatkan stratergi peningkatan keberhasilan pelaksanaan program PUMP-PB baik untuk

Tabel 3. Keadaan Program PUMP-PBKeseluruhan Komoditas pada Masa Depan. Table 3. Future Condition of PUMP Program.

\begin{tabular}{|c|c|c|c|c|c|c|}
\hline \multirow{2}{*}{\multicolumn{2}{|c|}{ Faktor/Factors }} & \multicolumn{5}{|c|}{ Spektrum Keadaan/ Kondisi Masa Depan/Condition Spectrum/Future Condition } \\
\hline & & A & B & C & D & $E$ \\
\hline \multirow[t]{2}{*}{1.} & $\begin{array}{l}\text { Tingkat dan } \\
\text { akses teknologi } \\
\text { / Level and } \\
\text { access of } \\
\text { technology }\end{array}$ & $\begin{array}{c}\text { Teknologi } \\
\text { berkembang, } \\
\text { akses meningkat / } \\
\text { technology evolve, } \\
\text { access increase }\end{array}$ & $\begin{array}{l}\text { Teknologi tidak } \\
\text { berkembang, } \\
\text { akses meningkat } \\
\text { / Technology not } \\
\text { evolve, access } \\
\text { increase }\end{array}$ & $\begin{array}{l}\text { Teknologi tidak } \\
\text { berkembang,akses } \\
\text { tidak meningkat } \\
\text { / Technology not } \\
\text { evolve, access not } \\
\text { increase }\end{array}$ & $\begin{array}{c}\text { Teknologi } \\
\text { berkembang, } \\
\text { akses tidak } \\
\text { meningkat / } \\
\text { Technology } \\
\text { evolve, access } \\
\text { increase }\end{array}$ & \\
\hline & & $(1 \mathrm{~A})$ & (1B) & (1C) & (1D) & (1E) \\
\hline 2. & $\begin{array}{l}\text { Ketepatan } \\
\text { Lokasi/ } \\
\text { Appropriateness } \\
\text { of site selection }\end{array}$ & $\begin{array}{l}\text { Lokasi sudah tepat/ } \\
\text { Appropriatelocation } \\
\qquad \text { (2A) }\end{array}$ & $\begin{array}{c}\text { Lokasi Kurang } \\
\text { tepat/Not } \\
\text { appropriatelocation } \\
\text { (2B) }\end{array}$ & $\begin{array}{c}\text { Lokasi Tidak } \\
\text { tepat/ Not } \\
\text { appropriatelocation } \\
\text { (2C) }\end{array}$ & & \\
\hline 3. & $\begin{array}{l}\text { Ketepatan } \\
\text { calon penerima } \\
\text { bantuan / The } \\
\text { accuracy of the } \\
\text { prospective } \\
\text { recipients }\end{array}$ & $\begin{array}{l}\text { Calon penerima } \\
\text { sudah tepat / } \\
\text { Appropriate } \\
\text { recipients } \\
\text { (3A) }\end{array}$ & $\begin{array}{l}\text { Calon penerima } \\
\text { tidak tepat / } \\
\text { Not appropriate } \\
\text { recipients } \\
\text { (3B) }\end{array}$ & & & \\
\hline & $\begin{array}{l}\text { Luas dan status } \\
\text { lahan /Broad } \\
\text { ownership and } \\
\text { land status }\end{array}$ & $\begin{array}{l}\text { Luas dan status } \\
\text { lahan meningkat / } \\
\text { Extent and status of } \\
\text { landincreased }\end{array}$ & $\begin{array}{l}\text { Luas dan status } \\
\text { lahan tetap / Extent } \\
\text { and status of the } \\
\text { land remains }\end{array}$ & $\begin{array}{l}\text { Luas lahan semakin } \\
\text { berkurang status } \\
\text { lahan meningkat / } \\
\text { Land area diminish } \\
\text { land status increase }\end{array}$ & $\begin{array}{l}\text { Luas lahan } \\
\text { semakin } \\
\text { bertambah status } \\
\text { lahan tetap / } \\
\text { Land area grow, } \\
\text { land status } \\
\text { remains }\end{array}$ & $\begin{array}{c}\text { Status tidak } \\
\text { terjamin dan } \\
\text { luas timpang } \\
\text { / Unsecured } \\
\text { status and } \\
\text { extensive } \\
\text { lame }\end{array}$ \\
\hline & & $(4 \mathrm{~A})$ & (4B) & $(4 \mathrm{C})$ & (4D) & (4E) \\
\hline 5. & $\begin{array}{l}\text { Ketepatan } \\
\text { turunnya } \\
\text { bantuan / } \\
\text { Timeliness } \\
\text { decline in aid }\end{array}$ & $\begin{array}{l}\text { Turun tepat waktu / } \\
\text { On time } \\
\text { (5A) }\end{array}$ & $\begin{array}{l}\text { Dana lambat turun } \\
\qquad / \text { Late } \\
\text { (5B) }\end{array}$ & & & \\
\hline \multirow[t]{2}{*}{6.} & $\begin{array}{l}\text { Dukungan } \\
\text { kebijakan } \\
\text { daerah / }\end{array}$ & $\begin{array}{l}\text { Mendukung / } \\
\text { Support }\end{array}$ & Tetap / remains & $\begin{array}{l}\text { Tidak mendukung / } \\
\text { Not support }\end{array}$ & & \\
\hline & $\begin{array}{l}\text { vSupport local } \\
\text { policy }\end{array}$ & $(6 \mathrm{~A})$ & $(6 B)$ & $(6 C)$ & (6D) & $(6 E)$ \\
\hline
\end{tabular}

Sumber: Data primer diolah, 2012/Source : Primary Data Processed, 2012 
keseluruhan komoditas maupun masing-masing komoditas (lele, udang, rumput laut dan ikan patin). Keduanya (keseluruhan dan masing-masing komoditas) dilakukan dengan mengekstraksi keadaan-keadaanyang mungkin dilaknasanakan pada masa depan (kondisi Tabel 3 yang dikoreksi dengan kondisi Tabel 4, Tabel 5, Tabel 6, Tabel 7, dan Tabel 8) yang dikaitkan dengan skenario pelaksanaan program tersebut pada masa datang (Tabel 9). Dengan langkah-langkah tersebut, diperoleh hasil analisis prospektif terkait dengan penentuan strategi peningkatan program PUMP-PB untuk keseluruhan komoditas seperti tertera pada Tabel 10, dan untuk masingmasing komoditas seperti tertera pada Tabel 11.
Berdasarkan hasil analisis prospektif (Tabel 10), diketahui bahwa spektrum keadaaan program PUMP-PB untuk keseluruhan komoditas pada masa datang adalah: Teknologi berkembang dengan akses yang meningkat atau baik (1A), namun lokasi yang dipilih dinilai masih kurang tepat $(2 \mathrm{~B})$ dan dana yang masih terlambat turun atau kurang baik (5B). Meskipun demikian program PUMP-PB pada masa datang memiliki calon penerima program yang sudah tepat (3A) diikuti dengan luas dan status lahan yang meningkat atau baik (4A) dan mendapatkan dukungan kebijakan daerah yang positif terhadap program PUMP-PB (6A).

Tabel 4. Keadaan yang tidak mungkin terjadi bersamaan untuk Program PUMP-PB Keseluruhan Komoditas pada Masa Depan.

Table 4. The situation is Not Likely to Occur Simultaneously for PUMP-PB Program in the Future.

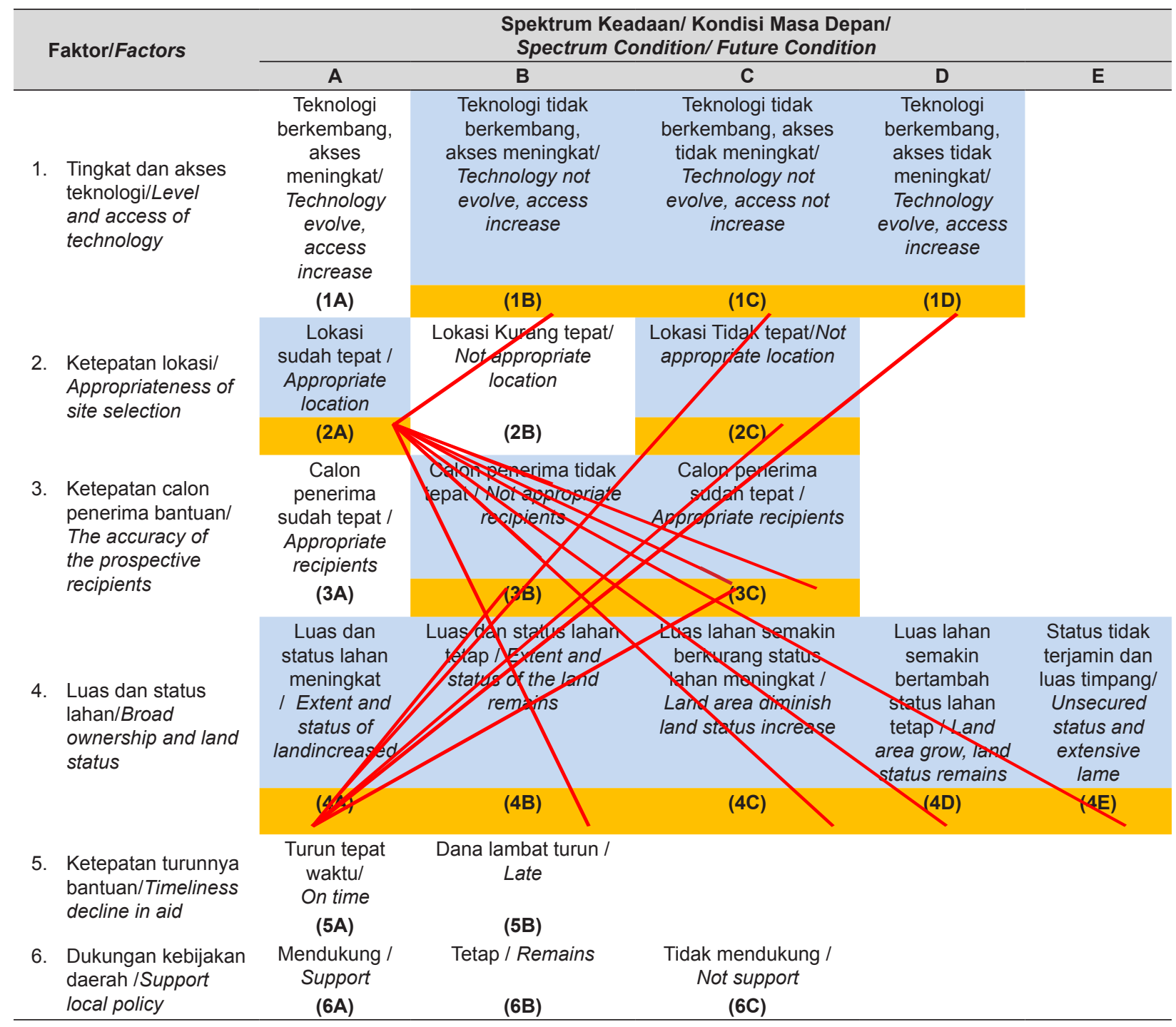

Sumber: Data primer diolah, 2012/Source : Primary Data Processed, 2012 
Tabel 5. Keadaan Yang Tidak Mungkin Terjadi Bersamaan Untuk Program PUMP-PB Lele Pada Masa Depan.

Table 5. The Situation is Not Likely to Occur Simultaneously For PUMP-PB Catfish Program in The Future

\begin{tabular}{|c|c|c|c|c|c|}
\hline \multirow{2}{*}{ Faktor/Factors } & \multicolumn{5}{|c|}{$\begin{array}{l}\text { Spektrum Keadaan/ Kondisi Masa Depan/ } \\
\text { Condition Spectrum/ Future Condition }\end{array}$} \\
\hline & A & B & C & D & $E$ \\
\hline \multirow[t]{2}{*}{$\begin{array}{l}\text { 1. Tingkat dan akses } \\
\text { teknologi / Level } \\
\text { and access of } \\
\text { technology }\end{array}$} & $\begin{array}{c}\text { Teknologi } \\
\text { berkembang, } \\
\text { akses meningkat } \\
\text { / Technology } \\
\text { evolve, access } \\
\text { increase }\end{array}$ & $\begin{array}{c}\text { Teknologi tidak } \\
\text { berkembang,akses } \\
\text { meningkat / } \\
\text { Technology not } \\
\text { evolve, access } \\
\text { increase }\end{array}$ & $\begin{array}{c}\text { Teknologi tidak } \\
\text { berkembang,akses } \\
\text { tidak meningkat } \\
\text { / Technology not } \\
\text { evolve, access not } \\
\text { increase }\end{array}$ & $\begin{array}{c}\text { Teknologi } \\
\text { berkembang,akses } \\
\text { tidak meningkat / } \\
\text { Technology evolve, } \\
\text { access increase }\end{array}$ & \\
\hline & $(1 \mathrm{~A})$ & (1B) & (1C) & (1D) & \\
\hline $\begin{array}{l}\text { 2. Ketepatan Lokasi / } \\
\text { Appropriateness of } \\
\text { Site Selection }\end{array}$ & $\begin{array}{l}\text { Lokasi sudah } \\
\text { tepat/Appropriate } \\
\text { location } \\
\text { (2A) }\end{array}$ & (2B) & & & \\
\hline $\begin{array}{l}\text { 3. Ketepatan calon } \\
\text { penerima bantuan } \\
\text { / The accuracy } \\
\text { of th prospective } \\
\text { recipients }\end{array}$ & $\begin{array}{l}\text { Calon penerima } \\
\text { sudah tepat } \\
\text { / Appropriate } \\
\text { recipients } \\
\text { (3A) }\end{array}$ & No & (3C) & & \\
\hline \multirow[t]{2}{*}{$\begin{array}{l}\text { 4. Luas dan status } \\
\text { lahan / Broad } \\
\text { ownership and land } \\
\text { status }\end{array}$} & $\begin{array}{l}\text { Luas dan status } \\
\text { lahan meningkat } \\
\text { / Extent and } \\
\text { status of } \\
\text { landincreased }\end{array}$ & $\begin{array}{l}\text { Extght } \\
\text { us of the } \\
\text { plains }\end{array}$ & $\begin{array}{l}\text { Luas lahan } \\
\text { semakin berkurang } \\
\text { status lahan } \\
\text { meningkat / Land } \\
\text { area diminish land } \\
\text { status increase }\end{array}$ & $\begin{array}{l}\text { Luas lahan } \\
\text { semakin } \\
\text { bertambah status } \\
\text { lahan tetap / Land } \\
\text { area grow, land } \\
\text { status remains }\end{array}$ & $\begin{array}{c}\text { Status tidak } \\
\text { terjamin } \\
\text { dan luas } \\
\text { timpang / } \\
\text { Unsecured } \\
\text { status and } \\
\text { extensive } \\
\text { lame }\end{array}$ \\
\hline & $(4 A)$ & (4B) & $(4 C)$ & (4D) & (4E) \\
\hline $\begin{array}{l}\text { 5. Ketepatan } \\
\text { Turunnya bantuan / } \\
\text { Timeliness decline } \\
\text { in aid }\end{array}$ & $\begin{array}{c}\text { Turun tepat } \\
\text { waktu / On time } \\
\text { (5A) }\end{array}$ & $\begin{array}{l}\text { Dana lambat turun } \\
\text { / Late } \\
\text { (5B) }\end{array}$ & & & \\
\hline \multirow{2}{*}{$\begin{array}{l}\text { 6. Dukungan } \\
\text { kebijakan daerah / } \\
\text { Support local policy }\end{array}$} & $\begin{array}{l}\text { Mendukung / } \\
\text { Support }\end{array}$ & Tetap / Remains & $\begin{array}{l}\text { Tidak mendukung / } \\
\text { Not support }\end{array}$ & & \\
\hline & $(6 A)$ & (6B) & $(6 C)$ & & \\
\hline
\end{tabular}

Sumber: Data primer diolah, 2012/Source : Primary Data Processed, 2012 
Tabel 6. Keadaan Yang Tidak Mungkin Terjadi Bersamaan Untuk Program PUMP-PB Udang Pada Masa Depan.

Table 6. The Situation is Not Likely to Occur Simultaneously for PUMP-PB Shrimp Program on the Future.

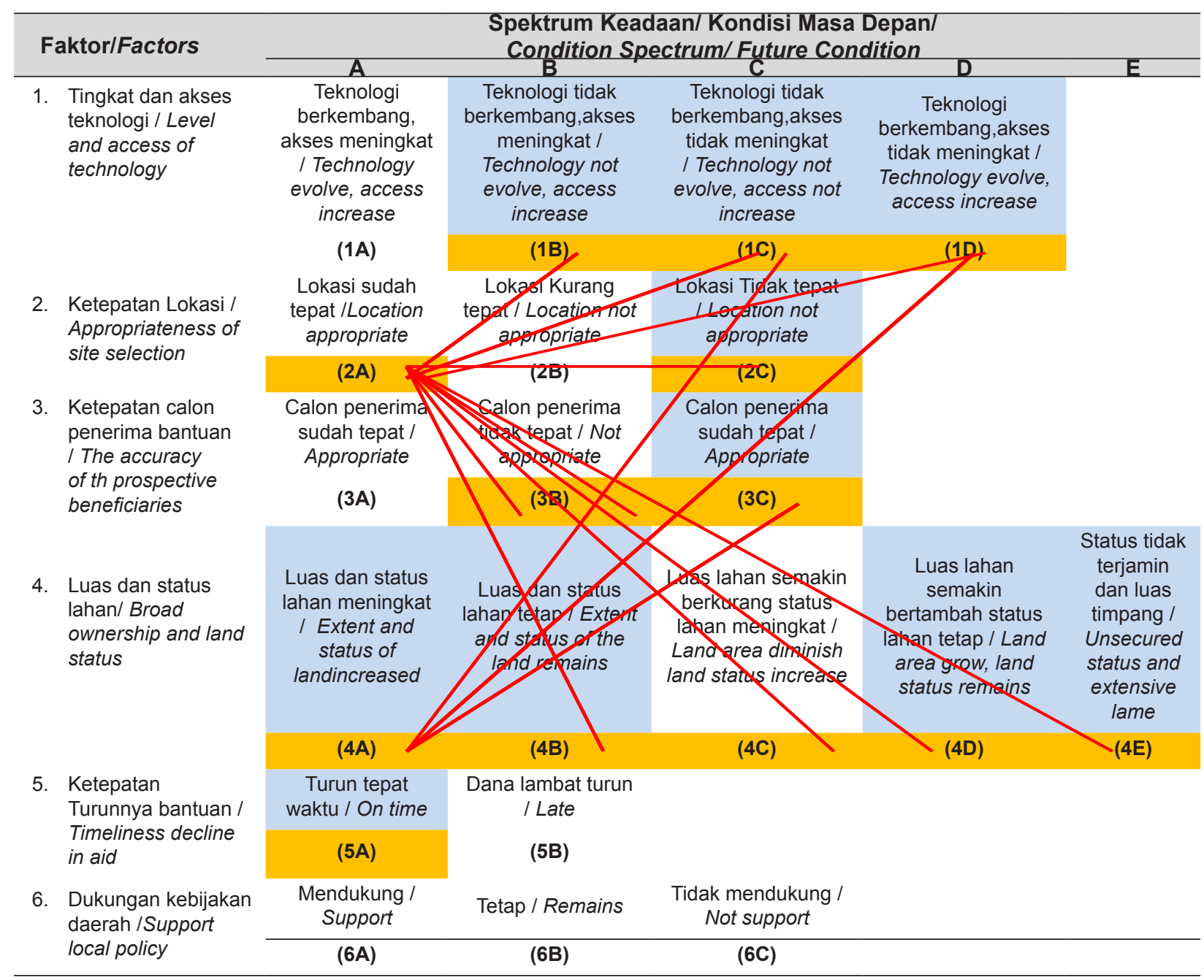

Sumber: Data primer diolah, 2012/Source : Primary Data Processed, 2012 
Tabel 7. Keadaan yang Tidak Mungkin Terjadi Bersamaan Untuk Program PUMP-PB Rumput Laut Pada Masa Depan.

Table 7. The Situation is Not Likely to Occur Simultaneously for PUMP-PB Seaweed Program on The Future.

\begin{tabular}{|c|c|c|c|c|c|c|}
\hline \multirow{2}{*}{\multicolumn{2}{|c|}{ Faktor/Factors }} & \multicolumn{5}{|c|}{$\begin{array}{l}\text { Spektrum Keadaan/ Kondisi Masa Depan/ } \\
\text { Condition Spectrum/ Future Condition }\end{array}$} \\
\hline & & A & B & C & D & $E$ \\
\hline 1. & $\begin{array}{l}\text { Tingkat dan akses } \\
\text { teknologi / Level } \\
\text { and access of } \\
\text { technology }\end{array}$ & $\begin{array}{c}\text { Teknologi } \\
\text { berkembang, } \\
\text { akses meningkat } \\
\text { / Technology } \\
\text { evolve, access } \\
\text { increase }\end{array}$ & $\begin{array}{l}\text { Teknologi tidak } \\
\text { berkembang, } \\
\text { akses meningkat } \\
\text { / Technology not } \\
\text { evolve, access } \\
\text { increase }\end{array}$ & $\begin{array}{c}\text { Teknologi tidak } \\
\text { berkembang,akses } \\
\text { tidak meningkat } \\
\text { / Technology not } \\
\text { evolve, access not } \\
\text { increase }\end{array}$ & $\begin{array}{c}\text { Teknologi } \\
\text { berkembang,akses } \\
\text { tidak meningkat / } \\
\text { Technology evolve, } \\
\text { access increase }\end{array}$ & \\
\hline & & $(1 \mathrm{~A})$ & (1B) & (1C) & (1D) & \\
\hline 2 , & $\begin{array}{l}\text { Ketepatan Lokasi / } \\
\text { Appropriateness of } \\
\text { site selection }\end{array}$ & $\begin{array}{c}\text { Lokasi } \\
\text { sudah tepa } \\
\text { Appropriate } \\
\text { location }\end{array}$ & Lokasi Kurang & & & \\
\hline 3. & $\begin{array}{l}\text { Ketepatan calon } \\
\text { penerima bantuan } \\
\text { /The accuracy of } \\
\text { the prospective } \\
\text { recipients }\end{array}$ & $\begin{array}{l}\text { Calon penerima } \\
\text { sudah tepat } \\
\text { / Appropriate } \\
\text { recipients }\end{array}$ & & & & \\
\hline 4. & $\begin{array}{l}\text { Luas dan status } \\
\text { lahan / Broad } \\
\text { ownership and land } \\
\text { status }\end{array}$ & $\begin{array}{l}\text { Luas dan status } \\
\text { lahan meningkat / } \\
\text { Extent and status } \\
\text { of landincreased }\end{array}$ & $(4 B) /$ & $\begin{array}{l}\text { semakin } \\
\text { status } \\
\text { ngkat / } \\
\text { liminish } \\
\text { ncrease }\end{array}$ & $\begin{array}{l}\text { Luas lahan semakin } \\
\text { bertambah status } \\
\text { lahan tetap / Land } \\
\text { area grow, land } \\
\text { status remains }\end{array}$ & $\begin{array}{l}\text { Status } \\
\text { tidak } \\
\text { terjamin } \\
\text { dan luas } \\
\text { timpang / } \\
\text { Unsecured } \\
\text { status and } \\
\text { extensive } \\
\text { lame } \\
\text { (4E) }\end{array}$ \\
\hline 5. & $\begin{array}{l}\text { Ketepatan } \\
\text { Turunnya bantuan / } \\
\text { Timeliness decline } \\
\text { in aid }\end{array}$ & $\begin{array}{l}\text { Turun tepat waktu } \\
\text { / on time }\end{array}$ & $\begin{array}{l}\text { Dand lambat } \\
\text { turun / late }\end{array}$ & & & \\
\hline 6. & $\begin{array}{l}\text { Dukungan } \\
\text { kebijakan daerah } \\
\text { / Support of local } \\
\text { policy }\end{array}$ & $\begin{array}{l}\text { Mendukung / } \\
\text { Support } \\
\text { (6A) }\end{array}$ & $\begin{array}{c}\text { Tetap / Remains } \\
\text { (6B) }\end{array}$ & $\begin{array}{l}\text { Tidak mendukung / } \\
\text { Not support } \\
\text { (6C) }\end{array}$ & & \\
\hline
\end{tabular}

Sumber: Data primer diolah, 2012/Source : Primary Data Processed, 2012 
Tabel 8. Keadaan Yang Tidak Mungkin Terjadi Bersamaan Untuk Program PUMP-PB Ikan Patin Pada Masa Depan.

Table8. The Situation lis Not Likely to Occur Simultaneously for The Program PUMP-PB Catfish on The Future.

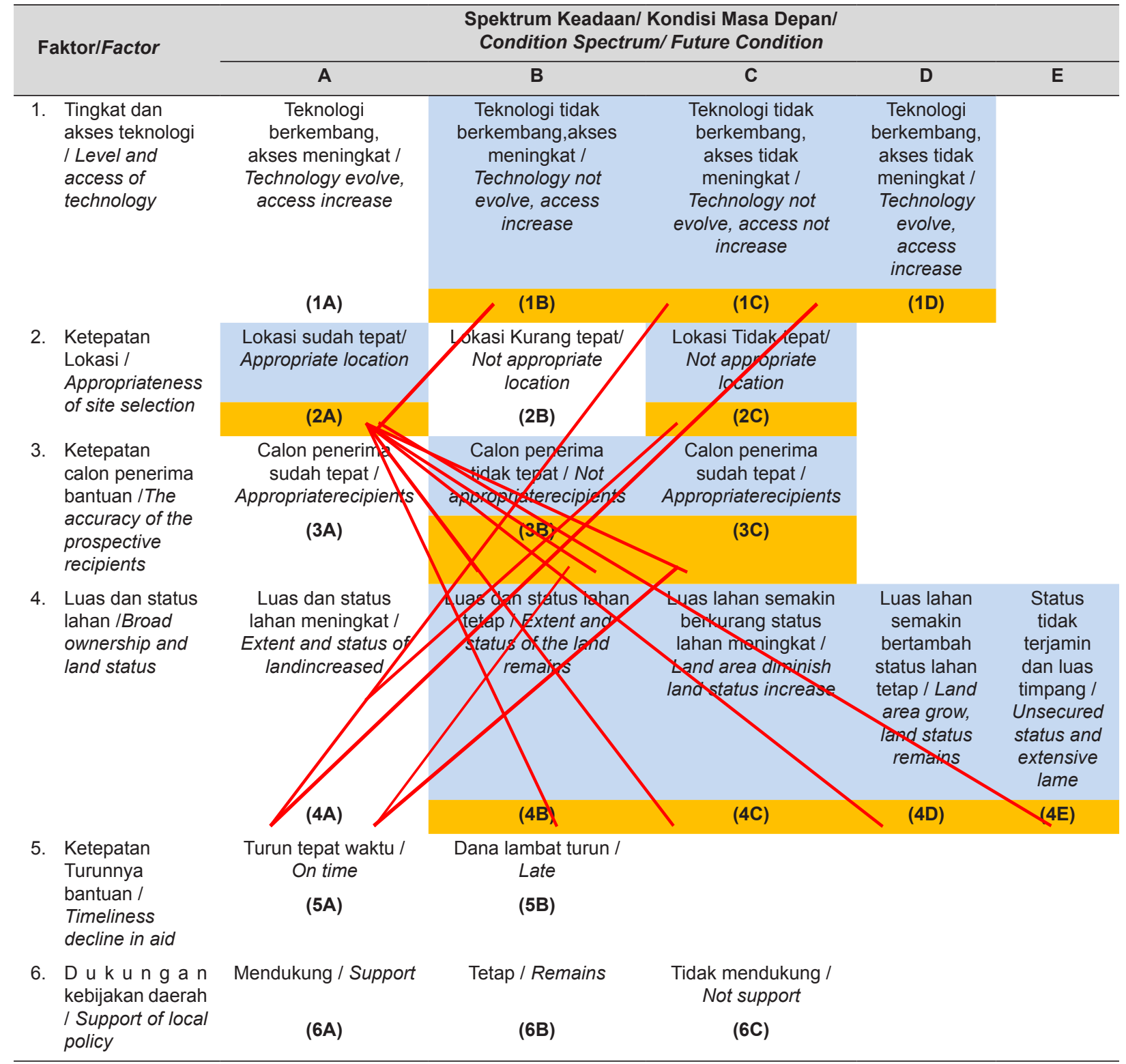

Sumber: Data primer diolah, 2012/Source : Primary Data Processed, 2012 


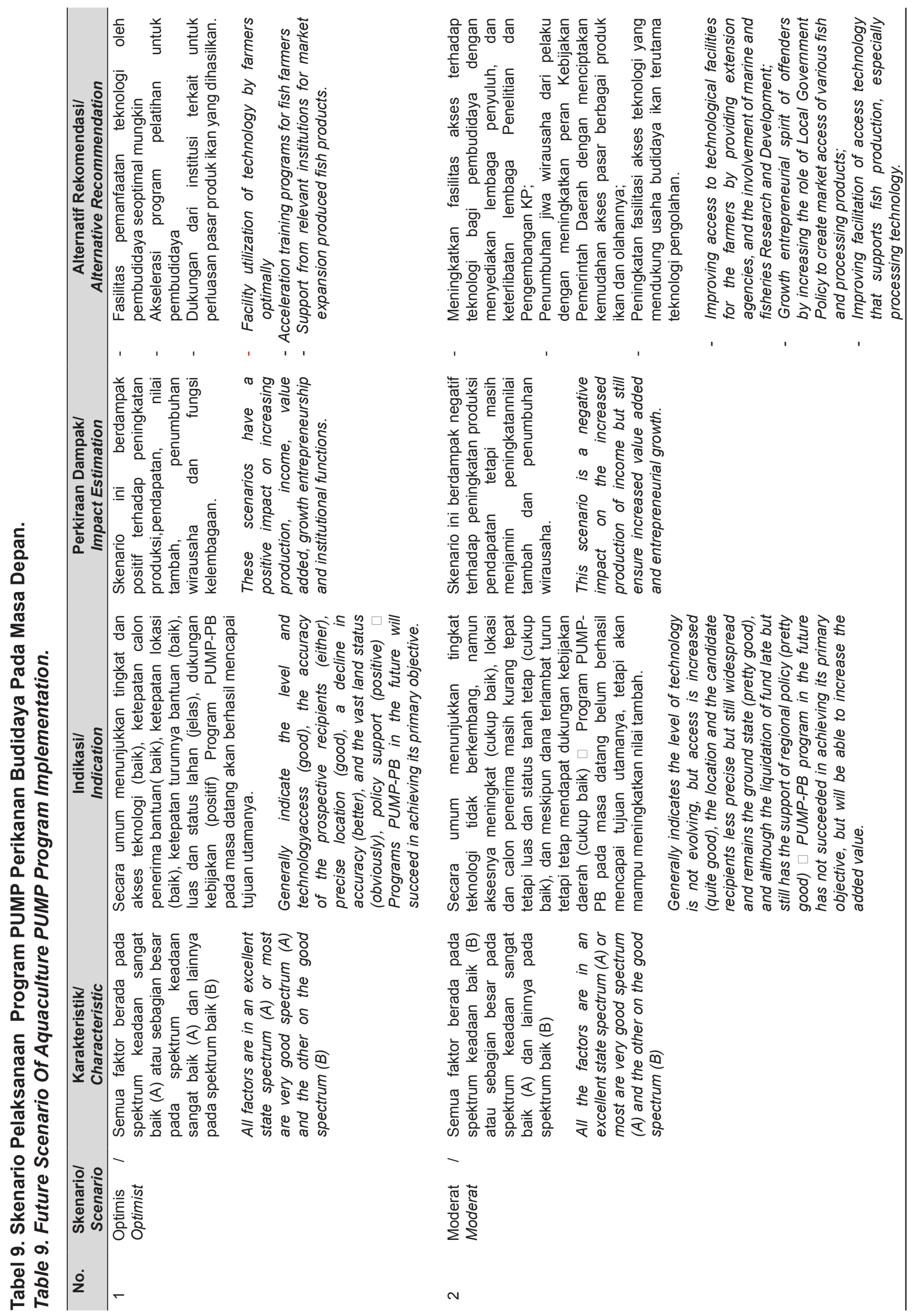




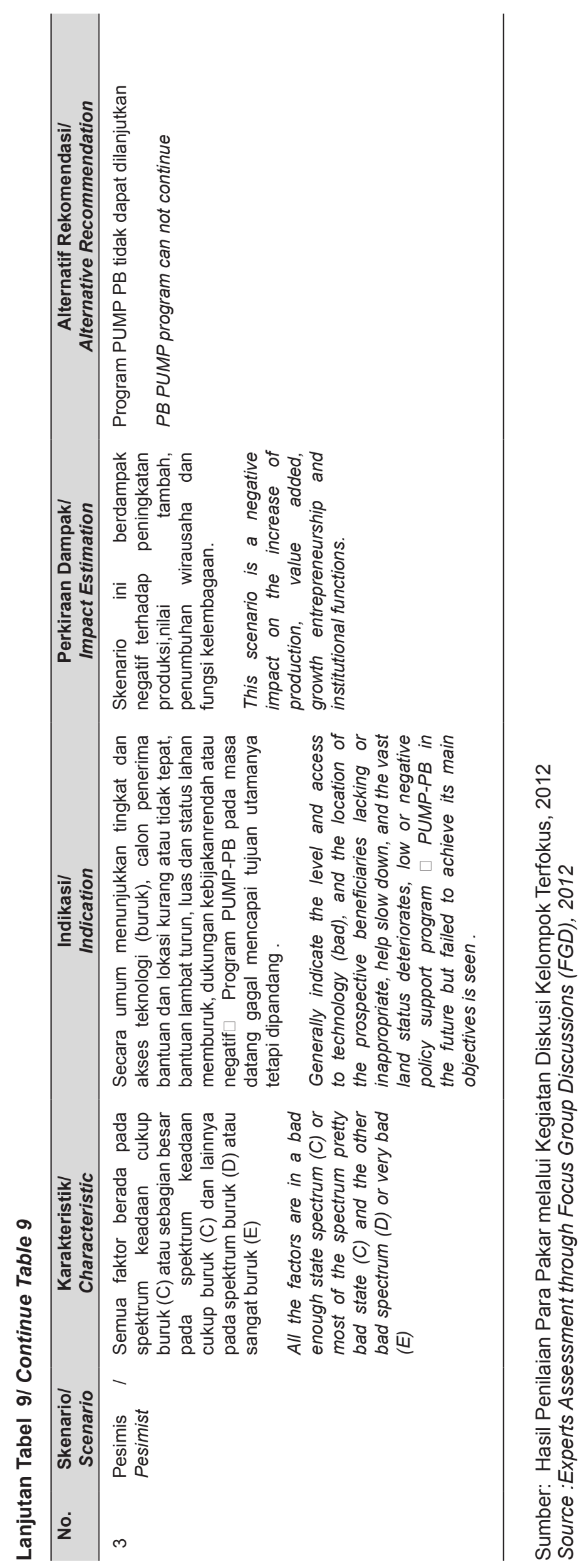


Tabel 10. Hasil Analisis Prospektif dalam Rangka Penentuan Strategi menurut Faktor, SpektrumKeadaan Masa Depan dan Keputusan Skenario Terpilih untuk Program PUMP-PB Keseluruhan Komoditas.

Table 10. Results of Prospective Analysis in Strategy Determination by Factor,Future Spectrum and Selected Scenarios for PUMP-PB Program for All Commodities.

\begin{tabular}{|c|c|c|}
\hline Faktor/Factors & $\begin{array}{c}\text { Spektrum Keadaan pada } \\
\text { Masa Depan/Future Condition } \\
\text { Spectrum }\end{array}$ & $\begin{array}{l}\text { Keputusan Skenario Terpilih/ } \\
\text { Selected Decision Scenario }\end{array}$ \\
\hline $\begin{array}{l}\text { 1. Tingkat dan akses teknologi } \\
\text { / Level and technology } \\
\text { access }\end{array}$ & $\begin{array}{l}\text { Teknologi berkembang, dengan akses } \\
\text { meningkat (1A) / Technology evolve, } \\
\text { access increase }\end{array}$ & $\begin{array}{l}\text { Urutan Faktor sesuai Spektrum } \\
\text { Keadaan Terpilih/Factors sequence }\end{array}$ \\
\hline $\begin{array}{l}\text { 2. KetepatanLokasi/ } \\
\text { Appropriateness of site } \\
\text { selection }\end{array}$ & $\begin{array}{l}\text { Lokasi Kurang tepat }(2 \mathrm{~B}) / \mathrm{Not} \\
\text { appropriate location }\end{array}$ & $\begin{array}{l}\text { appropriate with Selected Condition } \\
\text { Spectrum : (1A), (2B), (3A), (4A), } \\
\text { (5B), (6A) }\end{array}$ \\
\hline $\begin{array}{l}\text { 3. Ketepatan calon penerima } \\
\text { bantuan / The accuracy ofthe } \\
\text { prospective recipients }\end{array}$ & $\begin{array}{l}\text { Calon penerima sudah tepat / } \\
\text { Appropriate recipients }\end{array}$ & $\begin{array}{l}\text { Skenario terpilih/Selected Scenario: } \\
\text { Optimis }\end{array}$ \\
\hline $\begin{array}{l}\text { 4. Luas dan status lahan / } \\
\text { Broad ownership and land } \\
\text { status }\end{array}$ & $\begin{array}{l}\text { Luas dan status lahan meningkat (4A) } \\
\text { / Broad and land status increase }\end{array}$ & \\
\hline $\begin{array}{l}\text { 5. Ketepatan Turunnya } \\
\text { bantuan / Timeliness decline } \\
\text { in aid }\end{array}$ & $\begin{array}{l}\text { Dana lambat turun (5B) / Liquidation } \\
\text { of fund late }\end{array}$ & \\
\hline $\begin{array}{l}\text { 6. Dukungan kebijakan daerah/ } \\
\text { Support of local policy }\end{array}$ & Mendukung (6A) / Support & \\
\hline
\end{tabular}

Sumber: Sintesa berdasarkan hasil analisis prospektif (2012)

Source : Syntesis based on prospective analysis result (2012)

Tabel 11. Hasil Analisis Prospektif menurut Faktor, Spektrum Keadaan Masa depan dan Keputusan Skenario Terpilih untuk Program PUMP-PB Komoditas Lele, Udang, Rumput Laut dan Ikan Patin.

Table 11. Results of Prospective Analysis by Factor, Future Condition Spectrum and Selected Scenario Decision for PUMP-PB of Catfish,Shrimp, Seaweed dan Pangasius sp.

\begin{tabular}{|c|c|c|}
\hline Faktor/Factors & $\begin{array}{c}\text { Spektrum Keadaan pada } \\
\text { Masa Depan/Future Condition } \\
\text { Spectrum } \\
\end{array}$ & $\begin{array}{l}\text { Keputusan Skenario Terpilih/ } \\
\text { Selected Decision Scenario }\end{array}$ \\
\hline \multicolumn{3}{|l|}{ I. Lele / Catfish } \\
\hline $\begin{array}{l}\text { 1. Tingkat dan akses teknologi } \\
\text { / Level and access of } \\
\text { technology }\end{array}$ & $\begin{array}{l}\text { Teknologi berkembang, dengan akses } \\
\text { meningkat (1A) / Technology evolve, } \\
\text { access increase }\end{array}$ & $\begin{array}{l}\text { Urutan Faktor sesuai Spektrum } \\
\text { Keadaan Terpilih/Factors sequence }\end{array}$ \\
\hline $\begin{array}{l}\text { 2. KetepatanLokasi } \\
\text { Appropriateness of site } \\
\text { selection }\end{array}$ & $\begin{array}{l}\text { Lokasi Kurang tepat }(2 \mathrm{~B}) / \mathrm{Not} \\
\text { appropriate location }\end{array}$ & $\begin{array}{l}\text { appropriate with Selected Condition } \\
\text { Spectrum: } \\
\text { (1A), (2B), (3A), (4A), (5B), (6A) }\end{array}$ \\
\hline $\begin{array}{l}\text { 3. Ketepatan calon penerima } \\
\text { bantuan / The accuracy ofthe } \\
\text { prospective beneficiaries }\end{array}$ & $\begin{array}{l}\text { Calon penerima sudah tepat }(3 \mathrm{~A}) \text { / } \\
\text { Appropriate recipients }\end{array}$ & $\begin{array}{l}\text { Skenario terpilih/Selected Scenario: } \\
\text { Optimis }\end{array}$ \\
\hline $\begin{array}{l}\text { 4. Luas dan status lahan / Broad } \\
\text { ownership and land status }\end{array}$ & $\begin{array}{l}\text { Luas dan status lahan meningkat (4A) } \\
\text { / Broad and land status increase }\end{array}$ & \\
\hline $\begin{array}{l}\text { 5. Ketepatan Turunnya bantuan } \\
\text { / Timeliness decline in aid }\end{array}$ & $\begin{array}{l}\text { Dana lambat turun (5B) / Late fund } \\
\text { liquidation }\end{array}$ & \\
\hline $\begin{array}{l}\text { 6. Dukungan kebijakan daerah } \\
\text { / Support of local policy }\end{array}$ & Mendukung (6A) / Support & \\
\hline
\end{tabular}


Lanjutan Tabel 11/ Continue Table 11

\begin{tabular}{ccc}
\hline Faktor/Factors & $\begin{array}{c}\text { Spektrum Keadaan pada } \\
\text { Masa Depan/Future Condition } \\
\text { Spectrum }\end{array}$ & $\begin{array}{c}\text { Keputusan Skenario Terpilih/ } \\
\text { Selected Decision Scenario }\end{array}$ \\
\hline \hline
\end{tabular}

\section{Udang}

1. Tingkat dan akses teknologi Teknologi berkembang, dengan akses / Level and access of meningkat (1A)/ Technology evolve, technology

2. KetepatanLokasi Appropriateness of site appropriate location selection

3. Ketepatan calon penerima bantuan / The accuracy ofthe prospective beneficiaries

4. Luas dan status lahan /Broad ownership and land status

5. Ketepatan Turunnya bantuan / Timeliness decline in aid

Calon penerima kurang tepat (3B) /

Not appropriate recipients

Urutan Faktor sesuai Spektrum Keadaan Terpilih/Factors sequence appropriate with Selected Condition Spectrum:

(1A), (2A), (3B), (4B), (5B), (6A)

Skenario terpilih/Selected Scenario:

Luas dan status lahan Kurang meningkat (4B) / Broad and land status not increase

Moderat

Dana lambat turun (5B) / Late fund

liquidation

6. Dukungan kebijakan daerah I Support of local policy

\section{Rumput Laut}

1. Tingkat dan akses teknologi Teknologi berkembang, dengan akses I Level and access of meningkat (1C) / Technology evolve, technology

Mendukung (6A) / Support

2. KetepatanLokasi Appropriateness access increase

of Site appropriate location Selection

/ Lokasi Kurang tepat (2B) / Not

3. Ketepatan calon penerima bantuan /The accuracy ofthe prospective beneficiaries

4. Luas dan status lahan /Broad ownership and land status

5. Ketepatan Turunnya bantuan / Timeliness decline in aid

Calon penerima kurang tepat (3B) /

Not appropriate recipients

Luas dan status lahan meningkat (4A)

I Broad and land status increase

Dana lambat turun (5B)/Late fund liquidation

6. Dukungan kebijakan daerah I Support of local policy

Mendukung (6A) / Support
Urutan Faktor sesuai Spektrum Keadaan Terpilih/Factors sequence appropriate with Selected Condition Spectrum:

(1C), (2B), (3B), (4A), (5B), (6A)

Skenario terpilih/Selected Scenario: Moderat :

\section{Ikan Patin}

1. Tingkat dan akses teknologi Teknologi berkembang, dengan akses / Level and access of meningkat (1A)/ Technology evolve, technology

2. KetepatanLokasi Appropriateness of site access increase selection

/ Lokasi Kurang tepat (2B) / Not

Ketepatan calon penerima bantuan /The accuracy ofthe prospective beneficiaries

4. Luas dan status lahan/Broad Luas dan status lahan meningkat (4A) ownership and land status / Broad and land status increase

5. Ketepatan Turunnya bantuan Dana lambat turun (5B) / Late fund / Timeliness decline in aid liquidation

6. Dukungan kebijakan daerah Mendukung (6A) / Support / Support of local policy

Sumber: Sintesa berdasarkan hasil analisis prospektif,2012

Source : Syntesis based on prospective analysis result, 2012 
Dengan mempertimbangkan spektrum keadaan Program PUMP-PB pada masa datang, yang dikaitkan dengan skenario pelaksanaannya,dapat dinilai bahwa program PUMP-PB pada masa datang memiliki prospek yang baik (optimis). Diharapkan pelaksanaan Program PUMP-PB keseluruhan komoditas dengan prospek yang baik (optimis) tersebut. Berdasarkan skenario dalam Tabel 9, Program PUMP PB akan mampu memberikan dampak yang positif terhadap peningkatan produksi, pendapatan, nilai tambah, penumbuhan wirausaha dan fungsi kelembagaan, sehingga dinilai akan mampu mencapai tujuan utamanya pada masa datang. Dengan demikian, dapat ditentukan bahwa strategi peningkatan keberhasilkan pelaksanaan Program PUMP-PB keseluruhan komoditas pada masa datang adalah mengkuti skenario optimis, yaitu: (1) Meningkatkan fasilitas pemanfaatan teknologi oleh pembudidaya seoptimal mungkin. Menurut Zuhal, (2010), Sumberdaya Manusia yang menguasai Iptek merupakan kekuatan intelektual dan Iptek merupakan penggerak utama pertumbuhan ekonomi (2) Mendorong akselerasi program pelatihan untuk pembudidaya; dan (3) Meningkatkan dukungan dari institusi terkait untuk perluasan pasar produk ikan yang dihasilkan.

Selanjutnya, dengan langkah yang sama seperti pada keseluruhan komoditas, strategi peningkatan keberhasilan Program PUMP-PB untuk masing-masing komoditas (lele, udang, rumput laut dan ikan patin),adalah sebagai berikut:

(a) Strategi peningkatan keberhasilan Progran PUMP-PB komoditas lele dan ikan patin pada masa datang adalah mengikuti skenario optimis (dinilai mampu mencapai tujuan utamanya), yaitu sama dengan strategi untuk keseluruhan komoditas.

(b) Strategi peningkatan keberhasilan Progran PUMP-PB komoditas udang dan rumput laut pada masa datang adalah mengikuti skenario moderat (dinilai belum mampu mencapai tujuan utamanya, namun mampu meningkatkan nilai tambah), yaitu: (1) Meningkatkan fasilitas akses terhadap teknologi bagi pembudidaya dengan menyediakan lembaga penyuluh, dan keterlibatan lembaga Penelitian dan Pengembangan Kelautan dan Perikanan; (2) Penumbuhan jiwa wirausaha dari pelaku dengan meningkatkan peran Kebijakan Pemerintah Daerah dengan menciptakan kemudahan akses pasar berbagai produk ikan dan olahannya; dan (3) Peningkatan fasilitasi akses teknologi yang mendukung usaha budidaya ikan terutama teknologi pengolahan.

\section{PENUTUP}

Program PUMP-PB untuk keseluruhan komoditas memiliki prospek keberhasilan yang baik dalam mencapai tujuan utamanya.Sementara, untuk masing-masing komoditas, PUMP-PB komoditas lele dan ikan patin memiliki prospek keberhasilan yang baik dalam mencapai tujuan utamanya, sedangkan Program PUMP-PB komoditas udang dan rumput laut memiliki prospek keberhasilan yang cukup baik dalam mencapai tujuan utamanya. Di samping itu,keberhasilan dari Program PUMP-PB baik keseluruhan komoditas maupun masing-masing komoditas sangat dipengaruhi oleh enam faktor utama atau dominan, yaitu: (1) Tingkat dan akses teknologi budidaya, (2) Ketepatan lokasi, (3) Ketepatan calon penerima bantuan (4) Luas dan status lahan (5) Ketepatan turunnya bantuan, (6) Dukungan kebijakan daerah.

Strategi peningkatan keberhasilan pelaksanaan Program PUMP-PB keseluruhan komoditas pada masa datang adalah mengikuti skenario optimis, yaitu: (1) Meningkatkan fasilitas pemanfaatan teknologi oleh pembudidaya seoptimal mungkin; (2) Mendorong akselerasi program pelatihan untuk pembudidaya; dan (3) Meningkatkan dukungan dari institusi terkait untuk perluasan pasar produk ikan yang dihasilkan. Sementara, strategi peningkatan keberhasilan Program PUMP-PB untuk masing-masing komoditas (lele, udang, rumput laut dan ikan patin), adalah sebagai berikut:

(a) Strategi peningkatan keberhasilan Progran PUMP-PB komoditas lele dan ikan patin pada masa datang adalah mengikuti skenario optimis (dinilai mampu mencapai tujuan utamanya), yaitu sama dengan strategi untuk keseluruhan komoditas.

(b) Strategi peningkatan keberhasilan Progran PUMP-PB komoditas udang dan rumput laut pada masa datang adalah mengikuti skenario moderat (dinilai belum mampu mencapai tujuan utamanya, namun mampu meningkatkan nilai tambah), yaitu: (1) Meningkatkan fasilitas akses terhadap teknologi bagi pembudidaya dengan menyediakan lembaga penyuluh, dan keterlibatan lembaga Penelitian dan 
Pengembangan Kelautan dan Perikanan; (2) Penumbuhan jiwa wirausaha dari pelaku dengan meningkatkan peran Kebijakan Pemerintah Daerah dengan menciptakan kemudahan akses pasar berbagai produk ikan dan olahannya; dan (3) Peningkatan fasilitasi akses teknologi yang mendukung usaha budidaya ikan terutama teknologi pengolahan.

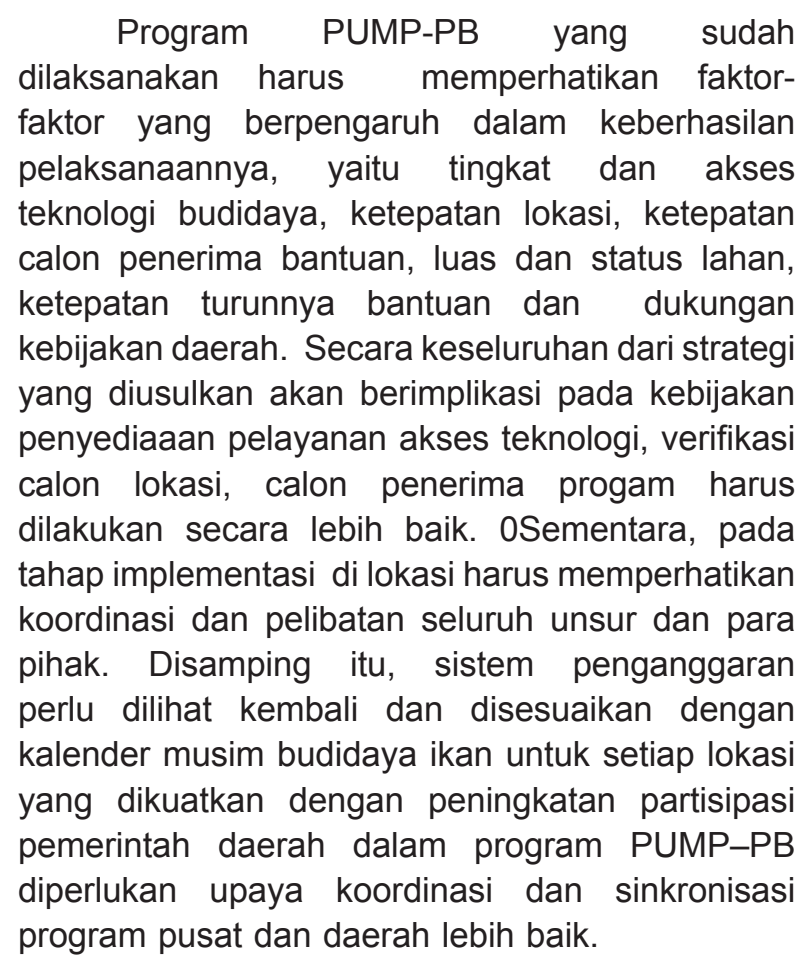

\section{DAFTAR PUSTAKA}

Alston, P., dan Bowles, J.E. 1998. Social Method and Research Analysis. Cambridge University Press. London.

Dinas Peternakan dan Perikanan Kabupaten Kolaka. 2012. Laporan Perkembangan Pokdakan PUMP 2011. Dinas Peternakan dan Perikanan Kabupaten Kolaka .

Godet, M. 2010. Future Memories. Technological

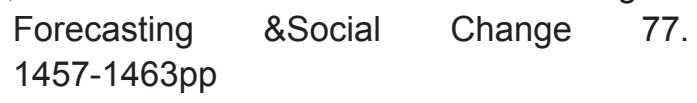

Hardjomidjojo, H. 2010. Metode Analisis Prospektif. Departemen Teknologi Industri Pertanian, Fakultas Teknologi, Institut Pertanian Bogor. Bogor.

Hoogerworf, A. 1983. Ilmu Pemerintah. Penerjemah R.L.L Tobing. Penerbit Erlangga. Jakarta.

Kementerian Kelautan dan Perikanan. 2012. Visi, misi, grand strategy dan sasaran strategis kkp. Pusdatin. KKP.

2010. Kelautan dan Perikanan dalam Angka. Pusat Data, Statistik dan Informasi, Kementerian Kelautan dan Perikanan. Jakarta.

Patton, M.Q. 1987. How to Use Qualitative Methods in Evaluation. The Regents of the University of California. Sage Publication Inc. California.

Priambodo, B.B. 2013. Ikan untuk Nelayan. Paradigma Undang-Undang Nomor 5 Tahun 1960 tentang Peraturan Dasar Pokok-Pokok Agraria Mengenai Pembangunan Perikanan Nasional Indonesia. Badan Penerbit Fakultas Hukum Universitas Indonesia. 201 hal.

Sukadi, F. 2002. Peningkatan Teknologi Budidaya Perikanan. Jurnal Iktiologi Indonesia Vol 2 (2) : 61-66.

Suradisastra, K. 2008. Strategi Pemberdayaan Kelembagaan Petani. Forum Penelitian Agro Ekonomi Vol 26 (2) : 82-91.

Suradisastra, K. 2008. Strategi Pemberdayaan Kelembagaan Petani. Forum Penelitian Agro Ekonomi Vol 26 (2) : 82-91.

Zuhal. 2010. Knowledge dan Innovation: Platform Kekuatan Daya Saing. PT. Gramedia Pustaka Utama. Jakarta. 485 hal. 